NBER WORKING PAPER SERIES

\title{
DO GRANTS TO CHARITIES CROWD OUT OTHER INCOME? EVIDENCE FROM THE UK
}

\author{
James Andreoni \\ A. Abigail Payne \\ Sarah Smith \\ Working Paper 18998 \\ http://www.nber.org/papers/w18998
}

\author{
NATIONAL BUREAU OF ECONOMIC RESEARCH \\ 1050 Massachusetts Avenue \\ Cambridge, MA 02138 \\ April 2013
}

We are very grateful to Renu Verma and Sarah Mistry for providing us with the data and for helpful discussions about the operation of Big Lottery and its predecessor, the Community Fund, and to David Clifford and the Third Sector Research Centre for providing us with the Charity Commission data. Edmund Wright provided excellent research assistance. Funding for this research was provided by the Economic and Social Research Council through the Centre for Market and Public Organisation and the Capacity Building Cluster on the Economic Impact of the Third Sector (co-funded by the Office of the Third Sector and the Barrow Cadbury Trust). Andreoni also thanks the National Science Foundation. The views expressed herein are those of the authors and do not necessarily reflect the views of the National Bureau of Economic Research.

NBER working papers are circulated for discussion and comment purposes. They have not been peerreviewed or been subject to the review by the NBER Board of Directors that accompanies official NBER publications.

(C) 2013 by James Andreoni, A. Abigail Payne, and Sarah Smith. All rights reserved. Short sections of text, not to exceed two paragraphs, may be quoted without explicit permission provided that full credit, including $\odot$ notice, is given to the source. 
Do Grants to Charities Crowd Out Other Income? Evidence from the UK

James Andreoni, A. Abigail Payne, and Sarah Smith

NBER Working Paper No. 18998

April 2013

JEL No. H3,H41,H44

\section{$\underline{\text { ABSTRACT }}$}

We present new evidence on the effect of grants on charities' incomes. We employ a novel identification strategy, focusing on charities that applied for lottery grant funding and comparing outcomes for successful and unsuccessful applicants. Overall, grants do not crowd out other income but the effect of grant-funding is not uniform. Looking in more detail we show first, that the positive effects of receiving a grant can persist for several years post-award; second, that grants have a stronger positive effect for small charities; and, third, that grants may have a more positive effect when they provide seed funding.

James Andreoni

Department of Economics

University of California, San Diego

9500 Gilman Drive

La Jolla, CA 92093-0508

and NBER

andreoni@ucsd.edu
Sarah Smith

CMPO, Department of Economics

University of Bristol

12 Priory Road

Bristol

BS8 1TN

sarah.smith@bristol.ac.uk

A. Abigail Payne

Department of Economics

McMaster University

KTH 426, 1280 Main Street West

Hamilton, Ontario, Canada L8S 4M4

paynea@mcmaster.ca 


\section{Introduction}

What effect does receiving a grant have on charities' incomes? Does the funding simply substitute for other sources of funding - do donors reduce their giving and/or do charities reduce their fundraising activities - or does the grant have a positive effect, helping charities to survive and thrive? This issue is crucially important for organisations that fund charities and has been a long-standing area of research (see, e.g., Andreoni (2006), List (2011), and Andreoni and Payne (2013) for summaries). The most recent empirical evidence from the US and Canada shows that donations fall when a charity receives a government grant. The main mechanism is not that donors respond directly to the grant by reducing their donations but that donations fall as a result of charities reducing their level of fundraising activity (Andreoni and Payne, 2011, 2012).

This paper studies this question using a unique sample of all the charities that applied for a grant from a program funded out of the UK National Lottery ticket proceeds. ${ }^{2}$ This allows us to employ empirical techniques that are novel for this area of research. Our analysis focuses on a sample of relatively homogeneous charities that have applied for funding that we can observe both before and after the funding application. We also observe the assessment criteria used to award funding and can narrow our analysis to those charities that narrowly succeeded to receive funding and those that narrowly failed to receive funding, allowing us to identify the effect of the grant funding on charity revenues. Focusing on a single funding program with information on the projects and the charity applicants also allows us to open up the "black box" of grant funding to

\footnotetext{
${ }^{2}$ The grants are funded out of the UK National Lottery "good causes" funding. Lottery funding represents an important source of income for charities in a number of countries. In the UK, National Lottery funding for charities totalled $£ 0.5$ billion in $2010-11$, compared to $£ 3.0$ billion in grants from the government. There has been relatively little evidence on the impact of this source of funding on charities (for a recent exception, see Jones, 2012).
} 
explore what types of grants, to what types of organisations are more or less associated with reduced funding from other sources.

We find that being awarded a grant has a positive and significant effect on a charity's total income. In other words, these grants do not crowd out other funding sources. Indeed, for some, smaller charities there is crowd in -- $£ 1$ of grant income actually increases income by more than $£ 1$. Our analysis points to a number of key reasons why our findings differ from previous studies. First, we show that the positive effect of being awarded a grant persists well beyond the year in which the grant was awarded (and the period over which the grant payments are likely to be made), highlighting the importance of assessing policy impacts over the longer-term.

Second, we show that the effect of grant funding varies by size of charity. For charities with large annual revenues $(£ 5 \mathrm{~m}+)$, the evidence suggests the charity may substitute across revenue sources. The positive effects are driven by smaller charities. Since the size of the lottery grants varies little by charity size, it is not surprising that being awarded a grant has a relatively bigger impact on smaller charities' total incomes. However, the per-pound effect of a grant is also greater for smaller charities. This may be because, compared to larger charities, smaller charities have fewer alternative funding sources for raising similar levels of income.

Third, we know something about the type of activities for which charities are typically seeking funding. Usually, it is money for a specific set of discrete (new or existing) activities. This is consistent with the idea suggested by Andreoni (1998) that seed funding can crowd in other income.

The plan of the paper is as follows: In the next section, we present a simple framework for thinking about the effect of lottery grant funding on a charity's total income. Section 3 describes 
the National Lottery good causes funding, and our data, in more detail. Section 4 discusses our empirical strategy and section 5 presents our main results. Section 6 concludes.

\section{A framework for assessing the effect of grant funding}

Our data contain reliable information on charities' total income, including grant income, (Y) and the amount of the lottery grant awarded $\left(\mathrm{G}_{1}\right)$. Our empirical tests are therefore:

(1) whether receiving a grant completely crowds out other sources of income: i.e. $\frac{d Y}{d G_{1}}=0$ and

(2) whether total income increases exactly in line with the increase in grant income, i.e.

$\frac{d Y}{d G_{1}}=\frac{d G_{1}}{d G_{1}}=1$, or whether it increases more or less pound-for-pound, which allows us to say something about whether there is crowd in versus crowd out.

To think about the various channels through which receiving a grant might affect a charity's total income, we borrow a simple, conceptual framework from Andreoni and Payne (2012). In practice, a charity's income will come from a number of different sources including donations from individuals (D) and grants from the government $\left(\mathrm{G}_{2}\right)$ and from other foundations $\left(\mathrm{G}_{3}\right)-$ each of which may respond directly to the charity being awarded a grant.. ${ }^{3}$

The charity will also spend money on activities to generate income from these different sources including fundraising activities directed at individual donors (FR) and grant applications directed at the government $\left(\mathrm{GA}_{2}\right)$ and other foundations $\left(\mathrm{GA}_{3}\right)$. The charity may adjust these activities following receipt of a grant, and this will also affect its income.

\footnotetext{
${ }^{3}$ The charity may also receive other sources of income from investments, sales and legacies that we assume to be unaffected by the grant.
} 
The overall effect of receiving a lottery grant on total income therefore depends on a number of direct and indirect effects as follows:

$$
\frac{d Y}{d G_{1}}=\frac{d D}{d G_{1}}+\frac{d D}{d F R} \frac{d F R}{d G_{1}}+\frac{d G_{1}}{d G_{1}}+\frac{d G_{2}}{d G_{1}}+\frac{d G_{2}}{d G A_{2}} \frac{d G A_{2}}{d G_{1}}+\frac{d G_{3}}{d G_{1}}+\frac{d G_{3}}{d G A_{3}} \frac{d G A_{3}}{d G_{1}}
$$

What does the existing theoretical and empirical literature say about the likely direction - and magnitude - of these elements?

The classic crowd out/neutrality result of Bergstrom, Blume, Varian (1986) and Warr (1982) relates to the direct effect of a grant on donations, $\mathrm{dD} / \mathrm{dG}_{1} \cdot{ }^{4}$ The result is based on an assumption that donors care only about the total level of public good. Crowd out will be less than pound-forpound, however, if donors also get some utility from the act of giving, such as a "warm glow" (Andreoni, 1990).

Recent empirical evidence has provided little support for direct crowd out either from government grants (Andreoni and Payne, 2011, 2012) or from lottery funding (Borg et al, 1991, Banks and Tanner, 1994, Lin and $\mathrm{Wu}, 2007, \mathrm{Wu}, 2012)$. A recent exception is Jones (2012) who looks at the effect of the introduction of education lotteries on donations in the US and finds a negative effect. However, these state lotteries differ slightly from the UK National Lottery in that their revenues are dedicated to a single purpose and allocated by the government rather than an indepdendent body.

Alternative mechanisms suggest channels through which grant funding could actually crowd in other income. One is a signalling story in which grants provide a signal to uninformed donors about the quality of a charity (Vesterlund, 2003, Andreoni, 2006). In this capacity, the grantfunder may act like a lead donor providing information to individuals about the charity, or the

\footnotetext{
${ }^{4}$ The result is based on government grants, but similar arguments apply to lottery funding.
} 
specific project for which the charity is raising money. Another story is that the grant provides seed funding for a new project - for example allowing a charity to cover fixed costs and expand its operations (Andreoni, 1998). These mechanisms could be particularly relevant to lottery grants which typically provide funding for discrete - and often new - projects. There has been some empirical support for crowd in effects in lab experiments (Bracha, Menietti and Vesterlund, 2011) and in field experiments (List and Lucking-Reilly, 2002, and Huck and Rasul, 2011). In relation to government grants to universities, Connolly (1997) shows a positive correlation between external and internal funding for academic research while Payne (2001) shows that an increase in government grants to a university increases private donations.

What about the direct effect of a lottery grant on other grant income, $\mathrm{dG}_{2} / \mathrm{dG}_{1}$ and $\mathrm{dG}_{3} / \mathrm{dG}_{1}$ ? Similar arguments are likely to apply as in the case of donations. Government and other funders may react to a charity receiving a lottery grant by reducing their funding because the marginal benefit of their funding is reduced. Alternatively, they may increase funding because the grant provides a quality signal and/or covers fixed costs. Most of the evidence points to a negative effect. Andreoni and Payne (2012b) provide some evidence that income from other foundations is negatively affected by a government grant, $\mathrm{dG}_{3} / \mathrm{dG}_{2}<0$. They suggest that the absence of a positive signalling effect is consistent with the view that other foundations are likely to be better informed that individual donors. Evidence from the US on the effect of lotteries on government financing of public goods also shows that the purported beneficiaries rarely experience a significant increase in state government spending $\left(\mathrm{dG}_{2} / \mathrm{dG}_{1} \leq 0\right)$. For example, Jones (2012) finds that education lotteries significantly increase revenue but fail to significantly increase education expenditures for education lotteries introduced between 1989 and 2008. 
There is less evidence on the direction and magnitude of indirect effects. As has been discussed, Andreoni and Payne (2011a, 2011b) provide evidence of a sizeable negative effect of grants on fundraising donations. However, it is plausible that if a grant acts as a signal of quality then the return to fundraising and grant applications - and expenditure on these activities - may actually increase.

In sum, the existing literature suggests that the effect of a grant on other sources of income is likely to be negative, but the discussion highlights the lack of a clear prediction. In the next section, we explain how we exploit the UK National Lottery good causes funding to provide new evidence on this issue.

\section{National Lottery funding}

This section describes the "good causes" program of the UK lottery, and how grant applicants for the funds are scored and selected. We go on to describe how the information from applications was matched with the panel data on charities' incomes and expenditures.

\subsection{The funding program}

Twentyeight pence from every $£ 1$ spent on the UK National Lottery is designated for "good causes" and is allocated to charities, small community groups and sports and arts organisations through five non-governmental bodies: The Community Fund (for charities), the New Opportunities Fund (for small community groups), ${ }^{5}$ the Heritage Lottery Fund (for historic buildings), the Arts Council of England and Sport England. ${ }^{6}$ We focus on one program, Grants for Large Projects, administered by the Community Fund. This was the single largest grant funding program for charities from the National Lottery money, accounting for 80 per cent of

\footnotetext{
${ }^{5}$ In 2005, the Community Fund and the New Opportunities Fund were merged to form the Big Lottery Fund.

${ }^{6}$ Note that the money was not allocated equally across the good causes. The Community Fund received 4.7 pence of the 28 pence allocated from the Lottery proceeds.
} 
total funding allocated by the Community Fund. ${ }^{7}$ We analyse a sample of 5,000+ applications

made to the Fund between 2002 and $2005^{8}$ - the distribution of applications and funding by year in our sample is shown in Table 1.

The stated aim of the Community Fund was to "help meet the needs of those at greatest disadvantage in society and also to improve the quality of life in the community". ${ }^{9}$ The Grants for Large Projects program was open to all charities seeking funding of $£ 60,000$ or more (the mean award in our sample was $£ 151,295$ ). The distribution of lottery grant funding tended to favour smaller charities relative to their sector share (i.e. their share of lottery funding was greater than their share of total income) and the grants awarded were relatively more important, relative to pre-award income, for smaller charities. This is illustrated in Table 2. Ignoring "micro" charities ${ }^{10}$ which are a relatively small and unrepresentative group of grant recipients, and focusing on "small" charities, the median grant among this group was more than twice the level of median pre-award income (note that grants could be paid over a period of up to three years), while for "major" charities (incomes $£ 5 \mathrm{~m}+$ ), the median grant was less than one per cent of pre-award income. Our analysis of the effects of grant funding finds that the degree of crowd out varies with charity size - and is greater for larger charities. The fact that the grants are relatively more important for smaller charities may help to explain why this might be the case.

\footnotetext{
${ }^{7}$ In addition to the Grants for Large Projects, the Community Fund also had a Medium Grants Program (£5,000 $£ 60,000)$, Awards for All (£500 - £5,000), and International Program and a Research Program.

${ }^{8}$ Our initial sample consists of 7,522 applications made between May 2002 and December 2005. We merge in information on charities' incomes and expenditures from the Charity Commission Register of charities, covering England and Wales - which together account for 6,196 applications. We then focus on 5,574 for which there is single application per project. We drop 13 observations where no definite outcome is recorded (defer/ in assessment), 370 observations where the requested amount was more than 5 times the charity's income (defined as mean income over the whole period) and 109 obs where information on income is missing over the whole period. Our final, cleaned sample consists of 5,071 applications

${ }^{9}$ There were six priority groups for funding - children and young people, older people and their carers, disabled people and their carers, black \& minority ethnic communities, refugee and asylum seekers and people in areas disadvantaged by social and economic change

${ }^{10}$ The split by size follows the National Council for Voluntary Organisations classification. Micro charities have incomes $<£ 10 \mathrm{~K}$ per annum; small charities have incomes $£ 10 \mathrm{~K}-£ 100 \mathrm{~K}$; medium charities have incomes $£ 100 \mathrm{~K}$ $£ 1 \mathrm{~m}$; large charities have incomes $£ 1 \mathrm{~m}-£ 5 \mathrm{~m}$; major charities have incomes $£ 5 \mathrm{~m}+$
} 
The Grants for Large Projects program typically funded specific projects--in each case the application described a set of activities to be funded. These activities could be the continuation of existing work or for beginning something completely new. The majority of applications (80 per cent) were for funding to cover the provision of services, 10 per cent were for the cost of staff or training activities, while the remaining 10 per cent were for capital projects. ${ }^{11}$ Below are some examples of proposed activities.

Services: "The project aims to provide a volunteer bureau service for the people living in [the town] and surrounding areas, which will also support people with learning disabilities, excluded young people and older people".

Staff/ training: "[the advice centre] wants to employ a diagnostic interviewer and receptionist to screen and signpost clients to decrease waiting time and increase capacity. Training will be provided to all staff on diagnostic interviewing."

Capital: "The project will replace a well used Brownie and Guide headquarters. The project will increase and improve activities for children and young people who access the centre."

\subsection{The application process}

Grants were awarded based on a two-stage assessment and a final committee meeting. The purpose of the first stage was to eliminate ineligible organisations and applications that clearly failed to meet the program or funding policies. Our data are from the second stage which involved a detailed assessment of the proposal based on a structured telephone interview and

\footnotetext{
${ }^{11}$ Most applicants did not have to match the funding received from the fund. The exception to the matching requirement was for charities with incomes of $£ 5$ million or more. These larger charities were required to contribute - or secure from other sources - at least 25 per cent of the total cost of their project.
} 
review of the application. In this second stage, proposals were scored along the following dimensions:

- Criterion 1 ("Management of Organization"): Whether the organisation is well-managed and financially sound (scored $0-1)$

- Criterion 2 ("Project Budget"): Whether the project budget is accurate and reasonable and is matched by realistic income projections (scored $0-6$ )

- Criterion 3 ("Serving Community"): Whether the organisation reflects the diversity of the community it serves and demonstrates appropriate levels of user involvement (scored $0-6$ )

- Criterion 4 ("Project Evaluation"): Whether the project has clearly-defined outcomes and outputs and a thorough and reasonable project plan that will be monitored and reviewed (scored $0-6)$

- Criterion 5 (“Impact of Project"): Whether the project helps to bring about long-term positive change in the needs of those at greatest disadvantage (scored $0-6$ )

- Criterion 6 ("Project Meets a Need"): Whether the project responds effectively to a clearly defined need (scored $0-6)$

- Criterion 7 ("Disadvantage"): Whether the project targets/ makes a difference to disadvantaged groups in the community (scored $0-6$ ).

For each of these criteria, the projects were scored on the basis of a number of specific subindicators. Examples for the first criterion (whether the organisation is well-managed) are given in Appendix A1, illustrating the comprehensive nature of the second-stage assessment. 
The final decision on whether to award funding was made by the relevant national or regional committee, typically made up of part-time (paid) members appointed by the executive staff overseeing the Fund. The assessments and scoring were important for the committees' deliberations, but they were not decisive. This is clear from Figure 1 which shows the proportion of applications funded by total score (note that for Figure 1 and in our subsequent analysis, each criterion score is normalised to score out of 1 to weight them all equally). While there is no "critical" threshold score either overall or for any single criterion (ruling out a regression discontinuity design), there is a positive relationship between score and likelihood of success. The reason for this range in scores v. award is likely due to funding priorities and the level of competition for funding at any particular point in time.

First, as a non-governmental public body, the Community Fund operated under policy directions from its sponsor department, the Department of Culture, Media and Sport. Mostly these related to the need to ensure a fair distribution of funding to organizations in terms of size, mission, and location. The committees could, therefore, exercise discretion under an effort to balance funding across these dimensions. Second, the committees faced budget constraints based on the expected level of revenues from the National Lottery. This meant that the chances of success could depend on the total amount of funding available and on the degree of competition at a particular committee meeting, i.e. the number and quality of the other applications being considered.

Table 3 reports the results from a probit regression of a binary variable indicating whether the application was successful. In the first column, we report the results using only the criterion scores. All of these have a positive and significant correlation with the likelihood of receiving funding. Column 2 includes additional controls (descriptive statistics are presented in Table 5). There is some evidence that charities that requested more funding were less likely to be 
successful, there is also variation in the likelihood of success tied to the total amount on the table and the timing of the committee meeting, both of which would reflect the degree of competition for funding, and some limited evidence that charity type matters.

The strength of the criteria in determining funding suggests a plausible identification strategy for assessing the effect of the grant on charity revenues. Namely, while we do not observe a sharp regression discontituity design, we exploit the criteria to identify a set of "marginal" charities that either just qualified or just failed to qualify for a grant. The latter group includes charities that scored well enough to be funded and that might have been successful if there were less competition at the time their application was considered/ if the committee did not have to consider the overall balance. Comparing outcomes for charities that just received funding with those that just failed gives us a credible strategy to identify the effect of receiving a grant on charity revenues. We provide more detail on our empirical identification strategy in Section 4.

\subsection{Matching information on charity incomes/ expenditures}

To complement the grants data we received from the Community Fund, we matched data on charity incomes for 2002-2008 from the Charity Commission register. The register covers all charities in England and Wales with annual incomes of $£ 5,000$ or more (charities with income below that level are not required to register). All registered charities must report their total income and expenditure to the Charity Commission; larger charities, those with incomes of $£ 500,000+$, are expected to report more detailed financial information but this is far from the case in practice and our analysis therefore focuses on the overall effect of receiving a grant on total income. 
In principle, if there were no missing observations, our sample would comprise 35,497 observations ( 5,107 organisations observed over seven years, from 2002 to 2008). In practice, as shown in Table 4, information on total income is missing for 13 per cent of our total potential sample. The number of missing observations is higher in the early years of the sample (three, four and five years before the committee decision). In all analysis, we therefore define our preperiod to be the two years prior to the committee decision.

The number of non-missing observations is higher among rejected applicants than among successful applicants in the post-award period. Since charities are expected to provide annual information to the charities commission, not filing information is a signal that the charity may no longer be in operation, pointing to a possible effect of a grant on charity survival. To explore this further, columns (3) and (4) in Table 3 report the results from estimating a Cox Proportional Hazards model; the dependent variable is a binary indicator equal to one if we observe sustained missing income ("charity exit"). In column (3) the estimation only uses information on whether a grant is awarded; the unconditional hazard ratio is 0.869 , suggesting that charities that receive grants are less likely to exit, but this is statistically insignificant. Including additional controls in column (4), the hazard ratio falls to 0.731 and becomes statistically significant at the 5 per cent level. This evidence suggests that being awarded a grant is linked to charity survival, something that has not been explored in previous studies. To the extent that we observe a positive effect on charity incomes, this will therefore be an under-estimate of the overall effect. 


\section{Empirical strategy}

\subsection{Testing for crowd out}

We first estimate a basic difference in differences (DD) specification to examine whether successful charities have higher incomes after the award decision:

$$
\ln y_{i t}=\alpha_{1}+\beta_{1} \text { Post }_{i t}+\gamma_{1} \text { Award }_{i t}+\lambda_{t}+v_{i}+\varepsilon_{i t}
$$

where $\ln y_{i t}$ is log total income of charity $i$ in period $t$ (including income from grants), Post ${ }_{i t}$ is an indicator variable equal to one if the charity is observed in a period after the committee met to take a decision on its application, $A w a r d i t$ is an indicator variable equal to one if the observation comes after the committee decision and the charity was successful, and $\lambda_{t}$ is a set of year indicator variables to capture macro-level shocks that would affect all charities similarly. We include charity-level fixed effects $\left(v_{i}\right)$, allowing us to control for unobservable, time-invariant characteristics of the charity (such as its efficiency in delivering services or management) that may be correlated with both the probability of being awarded a grant and the level of its income.

$\beta_{l}$ captures influences on income for all applicants in the post-award period whereas $\gamma_{1}$ captures the difference after the award decision for successful charities compared to those that are not successful. This specification allows us to assess whether or not there is complete crowd out, that is $\frac{d Y}{d G_{1}}=0$, by testing whether $\gamma_{l}=0$.

\subsection{Testing for crowd in}

Our second specification extends the analysis to incorporate information on the amount of grant income awarded: 


$$
y_{i t}=\alpha_{2}+\beta_{2} \text { Post }_{i t}+\gamma_{2}(\text { Post } \times £ \text { Amount })_{i t}+\lambda_{t}+v_{i}+\varepsilon_{i t}
$$

$y_{i t}$ is total income in pounds of charity $i$ in period $t$ (including income from grants) and £Amount is equal to the amount that the charity was awarded if successful and zero otherwise. In this model, the coefficient $\gamma_{2}$ provides an estimate of the effect of each pound of award on total income. Compared to estimating equation (1), this second specification allows us to test a wider range of crowd out/in effects, including complete crowd out $\left(\gamma_{2}=0\right)$, partial crowd out $\left(0<\gamma_{2}<\right.$ 1), "neutral" i.e. whether total income increases exactly in line with the grant awarded $\left(\gamma_{2}=1\right)$ and crowd in $\left(\gamma_{2}>1\right)$.

Lottery grants can be paid for (up to) three years. It is not clear in our data whether charities will report the full amount as part of their total income in one year or smooth it over several years. In addition, as we show below, the effect of receiving a grant on the charity's income appears to persist beyond the payment period. To deal with both these factors, we estimate equation (2) a number of times over different post-award period lengths: from the very first year post-award to (up to) five years post-award. For each post-award period length, we divide the award amount by the number of years' post-period, e.g. if we define the post-award period to be two years, we divide the total grant amount by two. In each case $\gamma_{2}$ captures the total effect on income per pound of grant, but over different lengths of time. We show that looking over a longer period, the per-pound effect of receiving a grant becomes more positive, pointing to long-term effects of grant funding. 


\subsection{Potential robustness checks}

Our identifying assumption is that the committee's decision to award a grant and the amount awarded is not correlated with contemporaneous shocks to the charity's income $\left(\varepsilon_{i t}\right)$. We carry out a number of robustness checks to test this.

Our first approach is to test the common trends assumption directly. We do this by estimating equation (1) including separate indicators for individual years before and after the award. Not only does this allow us to look at the dynamic effects of receiving a grant on charities' incomes, but it also allows us to test for any differential change in income between successful and unsucessful charities in the year prior to the committee's decision - this would be the case if award of the grant is linked to funding received or denied from other sources.

Our second approach is to narrow the sample to focus on successful and unsuccessful charities that are more closely comparable.

Following a standard approach in the literature suggested by Rubin (1974), we impose a common support across successful and unsuccessful charities using propensity scores based on the probit estimation of grant success with the wider set of controls presented in column (2) of Table 3.

We also create groups of "marginal" charities based on their overall grant proposal score, selecting charities that scored within a range that contained both successful and unsuccessful applicants. We define this range by committee meeting. As pointed out above while the scores received on the seven criteria are predictive of getting an award, they were not the sole determinant of success and we see charities receiving the same score that both were and were not 
awarded a grant. Given the comprehensive nature of the scoring process, we are confident that these factors do not reflect any unobservable quality of the organisation or the application. Instead, these are applications where it is plausible that success in securing a grant depended on exogenous factors to do with the committee's need to ensure portfolio balance and/or the timing of the application in being considered by a particular committee. We refer to the charities that were just funded/rejected as marginal charities because they are those that were just successful or that just missed out. Focusing on these marginal charities is likely to provide us with control and treatment groups that are more closely comparable in terms of project quality.

Specifically, we identify two sub-groups of marginal charities. First, we exploit the fact that the minimum score of successful applications is often less than the maximum score of rejected applications (see Figure 2, panel a). We select applications that scored above the minimum score of applications that were successful at the same committee meeting, but below the maximum score of the applications that were rejected. This defines a group of "within-meeting marginals" in the sense of being applications with scores that meant that the committee could have decided either way. Table 5 shows that the characteristics of successful and unsuccessful applications within this group of marginal applications are closer than in the overall sample. One concern might be that the decision was based on some factor related to the charity's future income growth that is unobservable to us, but was known to the committee. However, this concern is mitigated by the fact that the criterion scoring is so comprehensive. More likely, the outcomes in these cases reflect the fact that the committee used its discretion to ensure portfolio balance. This exercise of discretion is more common where the level of competition is higher, as shown in Table 5 by the fact that the sub group of within-committee marginal applications come from meetings with a higher level of funding sought and a higher level of applications. 
Our second group of marginal applications exploits variation across committee meetings in the average scores of successful applications (see Figure 2, panel b). We define "across-meeting marginals" as those that scored above the overall mean of successful applications and were unsuccessful and those that scored below the overall mean, but were successful. These are applications where the decision could have plausibly gone the other way if they were considered at a different meeting, reflecting the level of competition (the level of funding available and the number of applications being considered at any particular meeting). As shown in Table 5, the successful applications in this group typically faced a low level of competition (measured by the value of the other applications on the table), while unsuccessful applications faced a high level of competition.

\section{Empirical results}

\subsection{Testing for crowd out}

Table 6 presents the results from estimating equation (1), capturing the overall effect of receiving a grant on charity income. We test for complete crowd out $\left(\gamma_{1}=0\right)$ and clearly reject for the sample as a whole. This finding is robust to whether we use the full sample of all applicants (in panel a), the balanced sample (in panel c) or the sub-groups of marginal applicants (in panels $d$ and e). On average, being awarded a grant increased revenues by 20 per cent.

Panel $b$ shows that the effect of receiving a grant is similar for total expenditure as for total income. In other words, charities respond to a grant by increasing their activities and do not, for example, save out of the grant and use it to smooth fluctuations in other income streams through time. 
We run our regressions separately for different-sized charities. The grants are relatively more important for smaller charities (compared to their total income) and this is reflected in the fact that we find the strongest positive effects on revenues for small $(£ 10 \mathrm{k}-£ 100 \mathrm{k})$ and medium (£100k - £1m) charities. We find a smaller positive effect among large charities $(£ 1 \mathrm{~m}-£ 5 \mathrm{~m})$ which becomes insignificant in our second sub-group of marginal charities. We find that being awarded a grant actually has a negative effect on total income for major charities $(£ 5 \mathrm{~m}+)$ in the full sample, which would imply (more than) complete crowd out. This effect is statistically significant at the 10 per cent level.

The regression results in Table 6 capture the average effect of receiving a grant on post-award income over a period of (up to) five years after the award. Figure 3 illustrates the dynamic effects across individual years. We find no significant difference between successful and unsuccessful charities in the year prior to the committee decision, consistent with our identifying common trends assumption. This is an important robustness check that rules out that grants are awarded to charities that show better income growth prior to the committee decision and/or to charities that have received funds from elsewhere. It means, for example, that the Community Fund did not respond to decisions made by other grant-awarding bodies.

The dynamic analysis highlights that the impact on total income is fairly persistent - the incomes of successful charities are higher than those of unsuccessful charities for five years after the grant is awarded. Since the payment of the grant could be made over three years, i.e. over years 0,1 and 2, this means that the positive effect of funding on total income persisted for at least two years after the grant payment period. 


\subsection{Testing for crowd in}

Table 7 presents our main results, which exploit information on the amount of grant awarded, allowing us to measure the per-pound effect of grant income on charities' revenues. We report the p-value for the test that $\gamma_{2}=1$, i.e. that the effect of a grant is "neutral" with respect to other sources of funding $\left(\gamma_{2}=0\right.$ implies full crowd out, $0<\gamma_{2}<1$ implies partial crowd out, $\gamma_{2}=1$ implies no crowd out, while $\gamma_{2}>1$ implies crowd in). As before, we estimate the same model on the full sample (panel a), on the balanced sample (panel b) and on the two sub-groups of marginal applications.

Each coefficient comes from a separate regression in which we vary the length of the post-award period - from looking at just the year in which the committee met and took a decision (year 0) to looking at a five year period (years $0-4$ ). In each case, we divide the amount awarded by the number of years post award so that the coefficient captures the total effect of a pound of grant funding on a charity's income. Our results confirm that this longer-term perspective is important - for every $£ 1$ pound of grant income received, the total effect on charity revenues is greater and looks more positive - when viewed over a longer post-award period.

Again, we find that the effect of being awarded a grant is more positive for smaller charities than it is for larger charities. For the full sample of small and medium charities, the estimates of the per-pound effect of grant funding are significantly greater than one - consistent with crowd in. For small charities, each $£ 1$ of grant funding is estimated to increase total income by $£ 1.24$; the magnitude of this effect is robust to using narrower samples of balanced and marginal charities, although it loses significance because the sample size is reduced. For medium charities, the perpound effect for all charities is $£ 1.47$ - but this becomes smaller, as well as losing significance in 
the narrower samples. We find some evidence of relatively large positive and negative per pound effects for "large" and "major" charities, but these are less robust.

When looking at the percentage increase in total income, the larger positive effect for small charities may simply reflect the size of the grant relative to charities' income. The per-pound results, however, imply less of a (negative) response in other income sources when smaller charities receive a grant. Andreoni and Payne $(2003,2011,2012)$ have previously highlighted the importance of how charities respond to the award of a grant; in their results crowd out occurs not because donors respond directly to the charity receiving a grant but because charities reduce their fundraising activity. One possibility is that many smaller charities do not fundraise, but in separate analysis (not reported here, but available on request) we find a similar result looking only at charities that appear to engage in some fundraising. ${ }^{12}$ Another possibility is that smaller charities, even if they do fundraise, may find it hard to raise similar levels of funding to that provided by the lottery grant from other sources. For larger charities lottery grants are more likely to represent only one in a wide range of range of different funding options that can all potentially deliver funding at similar - or higher - levels. This would make it more likely that a grant is replaced by other income for larger charities than for smaller.

\subsection{Further analysis}

Finally, we explore whether there are differences in the effect of a being awarded a grant according to the purpose of the funding. Based on the description of the project, we define the purpose of funding as being for service provision, staff, or capital. As shown in Table 8 (panel a), we find that, compared to the omitted category (services), there is much stronger evidence of

\footnotetext{
${ }^{12}$ We use (imperfectly measured) spending on fundraising to define charities that definitely do engage in fundraising. Crowd out is not stronger for these charities.
} 
complete crowd out for capital projects, but no difference when the funding is for staff. To the extent that capital funding was largely sought for refurbishment of existing buildings, these results suggest that crowd out may be much lower when the funding is for new and additional activities. This gives some support to the idea (discussed in Andreoni, 1998) that grant funding crowds in other funding when it provides seed funding for a new project.

We also find significant differences in the impact of receiving a grant by charity type (shown in Table 8). ${ }^{13}$ The omitted category is social services charities (the largest single group among applicants). Compared to this group, we find that the effect of receiving a grant has a significantly larger positive effect on total income among health, environmental, international and religious charities. We do not have a simple explanation for these differences, but this finding adds to the overall picture that crowd out is not uniform but depends on where the grant funding is targeted.

\section{Discussion and conclusions}

This paper has provided new evidence on the effect of grant funding on charities' incomes. We exploit information on the allocation process for UK National Lottery grants to identify "marginal" charities that either just did receive or just did not receive funding. This is a novel approach to identifying the effect of grant funding that could be extended to other schemes. Overall, we find that grants do not crowd out other sources of income. Our analysis yields a number of new insights compared to previous studies: First, we show that there are important dynamics and that the positive effects of grants may be felt over several years. Second, we find some evidence that grants may improve a charity's chance of survival. Finally, focusing on a single grant programme allows us to peer into the "black box" of grant funding and show that the

\footnotetext{
${ }^{13}$ We adopt a standard ICNPO classification derived by the NCVO
} 
details of the funding programme are important in determining the exact effect of grant funding on charity incomes, including the size of the charity and the purpose of the funding.

Our results show that grants have a positive effect on revenues for smaller charities. The lottery grants are large relative to smaller charities' incomes (often as large as the charity's annual income) and one plausible explanation is that smaller charities have few alternative options for raising similar levels of funding. This suggests that grants may play a pivotal role in the funding portfolios of some charities. 


\section{References}

Andreoni. J. (1989) "Giving with impure altruism: applications to charity and ricardian equivalence” The Journal of Political Economy, page 1447-1458

Andreoni, J. (1990) "Impure Altruism and Donations to Public Goods: A Theory of Warm-Glow Giving.” The Economic Journal, 100: 464-477

Andreoni, J. (1998) Towards a theory of charitable fundraising Journal of Political Economy, vol. 106 , no. 6

Andreoni, J. and A.A. Payne (2003) Do government grants to private charities crowd out giving or fund-raising?. The American Economic Review, 93(3):792-812

Andreoni, J. and Payne, A. (2011) "Is crowding out due entirely to fundraising? Evidence from a panel of charities" Journal of Public Economics, 2011

Andreoni, J. and Payne, A. (2012) Crowding-out Charitable Contributions in Canada: New Knowledge from the North, NBER working paper

Andreoni, J. and Payne, A. (2013) "Charitable Giving," for Handbook of Public Economics (eds) Alan Auerbach, Raj Chetty, Martin Feldstein, and Emmanuel Saez

Banks, J. and Tanner, S. (1998) "The state of donation: Household gifts to charity, 1978-96" IFS Commentary http://econpapers.repec.org/paper/nerucllon/http 3a 2f 2fdiscovery.ucl.ac.uk 2f14789 2 f.htm

Bergstrom, T.C., L. Blume, and H. Varian. (1986) "On the private provision of public goods" Journal of public economics, 29(1):25-49

Bracha, A. Menietti, M and Vesterlund, L. (2011) "Sequential giving to public projects" Journal of Public Economics, Volume 95, p.416-427

Borg, M.O., P.M. Mason, and S.L. Shapiro. The economic consequences of state lotteries. Greenwood Publishing Group, 1991.

Huck, S. and Rasul, I. (2011) Matched fundraising: Evidence from a natural field experiment, Journal of Public Economics, 95, $351-362$

Jones, D. (2012) State lotteries and charitable donations, mimeo

Lin, E.S. and S.Y. Wu (2007) "Lottery expenses and charitable contributions--taiwan's experience" Applied Economics, 39(17):2241--2251

List, J. (2011) “The Market for Charitable Giving,” Journal of Economic Perspectives, 25(2): pp. 157-180. 
List, J. and Lucking-Reiley (2002) "The effects of seed money and refunds on charitable giving: Experimental evidence The Journal of Political Economy

Morgan, J. (2000) Financing public goods by means of lotteries. Review of Economic Studies, 67(4):761--784, 2000.

Morgan, J. and Sefton, M. (2000) "Funding public goods with lotteries: experimental evidence" The Review of Economic Studies, 67(4):785

Payne, A. (2001) "Measuring the Effect of Federal Research Funding on Private Donations at Research Universities: Is Federal Research Funding More than a Substitute for Private Donations?" International Tax and Public Finance, 8, 731-51

Rubin, D. B. (1974) 'Estimating Causal Effects of Treatments in Randomised and Nonrandomised Studies, Journal of Educational Psychology, 66, 688-701

Vesterlund, Lise (2003) “The Informational Value of Sequential Fundraising." Journal of Public Economics 87:627-58.

Warr, Peter (1982) "Pareto optimal redistribution and private charity", Journal of Public Economics, vol. 19 (1) (October), pp. 131-8.

Wu, S. (2012) "Does charitable gambling crowd out charitable donations?--using matching to analyze a natural experiment" mimeo 
Table 1: Applications and awards, by year

\begin{tabular}{|c|c|c|c|c|c|c|c|c|}
\hline $\begin{array}{c}\text { Year of Committee } \\
\text { Decision }\end{array}$ & $\begin{array}{c}\text { \# of } \\
\text { Committee } \\
\text { Meetings }\end{array}$ & $\begin{array}{l}\text { Total \# of } \\
\text { Applicants }\end{array}$ & $\begin{array}{c}\% \text { of } \\
\text { Successful } \\
\text { Applicants }\end{array}$ & $\begin{array}{c}\text { Total } \\
\text { Amount } \\
\text { Awarded } \\
\text { (£millions) }\end{array}$ & $\begin{array}{c}\text { Total } \\
\text { Amount } \\
\text { Requested } \\
\text { (£Millions) }\end{array}$ & $\begin{array}{c}\text { Minimum } \\
\text { Amount } \\
\text { Awarded }\end{array}$ & $\begin{array}{l}\text { Median } \\
\text { Amount } \\
\text { Awarded }\end{array}$ & $\begin{array}{c}\text { Maximum } \\
\text { Amount } \\
\text { Awarded }\end{array}$ \\
\hline $2002($ Sept - Dec $)$ & 16 & 209 & $56.9 \%$ & $£ 19.3$ & $£ 39.0$ & $£ 3,506$ & $£ 137,563$ & $£ 628,648$ \\
\hline 2003 & 57 & 1385 & $60.9 \%$ & $£ 130.0$ & $£ 246.5$ & $£ 4,550$ & $£ 144,293$ & $£ 819,220$ \\
\hline 2004 & 46 & 1472 & $46.3 \%$ & $£ 102.7$ & $£ 261.4$ & $£ 1,304$ & $£ 142,282$ & $£ 518,364$ \\
\hline 2005 & 54 & 1735 & $70.4 \%$ & $£ 172.3$ & $£ 279.1$ & $£ 1,500$ & $£ 134,899$ & $£ 717,040$ \\
\hline $2006(\mathrm{Jan}-\mathrm{Feb})$ & 8 & 270 & $80.7 \%$ & $£ 32.1$ & $£ 45.1$ & $£ 2,500$ & $£ 132,819$ & $£ 737,410$ \\
\hline Whole period & 181 & 5,071 & $60.7 \%$ & $£ 456.4$ & $£ 871.1$ & $£ 1,304$ & $£ 138,702$ & $£ 819,220$ \\
\hline
\end{tabular}

Notes to table: All figures refer to our cleaned sample of 5,071 lottery grant applicants. Further details on this sample are provided in section 3.1 . 
Table 2: Distribution of funding, by charity size

\begin{tabular}{|c|c|c|c|c|c|c|c|}
\hline & $\%$ population & $\begin{array}{l}\% \text { sector } \\
\text { income }\end{array}$ & $\begin{array}{l}\text { \% Lottery } \\
\text { grants } \\
\text { awarded }\end{array}$ & Success rate & $\begin{array}{l}\% \text { Lottery } \\
\text { funding }\end{array}$ & $\begin{array}{c}\text { Median grant } \\
\text { size }\end{array}$ & $\begin{array}{l}\text { Median } \\
\text { income }\end{array}$ \\
\hline Micro $(<£ 10 \mathrm{~K})$ & $53.5 \%$ & $0.6 \%$ & $2.8 \%$ & $72.0 \%$ & $2.4 \%$ & $£ 121,793$ & $£ 5,433$ \\
\hline Small (£10K - £100K) & $31.2 \%$ & $4.9 \%$ & $24.8 \%$ & $62.0 \%$ & $21.1 \%$ & $£ 119,785$ & $£ 54,143$ \\
\hline Medium $(£ 100 \mathrm{~K}-£ 1 \mathrm{~m})$ & $12.5 \%$ & $17.2 \%$ & $52.0 \%$ & $60.2 \%$ & $52.3 \%$ & $£ 140,000$ & $£ 278,864$ \\
\hline Large $(£ 1 \mathrm{~m}-£ 5 \mathrm{~m})$ & $2.5 \%$ & $30.9 \%$ & $10.8 \%$ & $55.6 \%$ & $13.4 \%$ & $£ 165,741$ & $£ 2,120,587$ \\
\hline Major $(£ 5 m+)$ & $0.3 \%$ & $46.4 \%$ & $9.7 \%$ & $63.9 \%$ & $10.6 \%$ & $£ 139,907$ & $£ 26,615,820$ \\
\hline
\end{tabular}

Notes to table: The size categories have been defined by the UK National Council for Voluntary Organisations. Information on the population distributions also comes from the NCVO, based on data provided by the Charity Commission. Median income refers to successful lottery grant applications; it is measured over the pre-award period. All figures refer to our cleaned sample of 5,071 lottery grant applicants. 
Table 3: Grant application success

Probit model, marginal effects

Dependent variable $=$ grant awarded $(0 / 1)$

Cox Proportion Hazards model, Hazard ratio Dependent variable $=$ charity exit $(0 / 1)$

\begin{tabular}{|c|c|c|c|c|c|c|c|c|c|c|c|}
\hline & \multicolumn{3}{|c|}{ (1) } & \multicolumn{3}{|c|}{ (2) } & \multicolumn{2}{|c|}{ (3) } & \multicolumn{3}{|c|}{ (4) } \\
\hline & Coeff & & SE & Coeff & & SE & Coeff & SE & Coeff & & SE \\
\hline Grant awarded $(0 / 1)$ & & & & & & & 0.8811 & $(0.086)$ & 0.7306 & ** & $(0.104)$ \\
\hline Criterion 1 Management of Org & 0.910 & *** & $(0.164)$ & 1.017 & *** & $(0.194)$ & & & 0.6515 & & $(0.189)$ \\
\hline Criterion 2 Project Budget & 2.623 & *** & $(0.213)$ & 2.714 & *** & $(0.244)$ & & & 5.9883 & **** & $(3.490)$ \\
\hline Criterion 3 Serving Community & 1.294 & *** & $(0.240)$ & 1.509 & ${ }^{* * *}$ & $(0.273)$ & & & 0.6662 & & $(0.399)$ \\
\hline Criterion 4 Project Evaluation & 2.444 & *** & $(0.224)$ & 2.717 & ${ }^{* * *}$ & $(0.254)$ & & & 0.6244 & & $(0.358)$ \\
\hline Criterion 5 Impact of Project & 2.717 & ${ }^{* * *}$ & $(0.232)$ & 2.820 & **** & $(0.263)$ & & & 1.7657 & & $(0.988)$ \\
\hline Criterion 6 Project Meets Need & 2.115 & *** & $(0.223)$ & 2.399 & ${ }^{* * *}$ & $(0.249)$ & & & 1.4034 & & $(0.809)$ \\
\hline Criterion 7 Disadvantage & 0.419 & & $(0.044)$ & 0.393 & ${ }^{* * *}$ & $(0.052)$ & & & 0.8647 & & $(0.109)$ \\
\hline Ln charity income & & & & -0.005 & & $(0.014)$ & & & 0.8188 & **** & $(0.030)$ \\
\hline Ln amount requested & & & & -0.056 & ${ }^{* * *}$ & $(0.017)$ & & & 1.0802 & & $(0.122)$ \\
\hline Funding for services & & & & & & & & & & & \\
\hline Funding for staff & & & & -0.065 & & $(0.080)$ & & & 1.2716 & & $(0.206)$ \\
\hline Funding for capital & & & & 0.136 & & $(0.089)$ & & & 0.3966 & ${ }^{* * *}$ & $(0.097)$ \\
\hline Funding for development & & & & -0.016 & & $(0.068)$ & & & 0.8897 & & $(0.130)$ \\
\hline Total on table & & & & -0.009 & * & $(0.004)$ & & & 1.0011 & & $(0.011)$ \\
\hline Quarter 2 & & & & -0.408 & ${ }^{* * * *}$ & $(0.073)$ & & & 0.9448 & & $(0.157)$ \\
\hline Quarter 3 & & & & -0.054 & & $(0.060)$ & & & 0.9359 & & $(0.128)$ \\
\hline Quarter 4 & & & & 0.259 & *** & $(0.067)$ & & & 0.9545 & & $(0.160)$ \\
\hline Social services & & & & & & & & & & & \\
\hline Culture & & & & -0.140 & & $(0.136)$ & & & 0.4640 & * & $(0.195)$ \\
\hline Education & & & & -0.177 & & $(0.111)$ & & & 1.4150 & & $(0.324)$ \\
\hline Health & & & & 0.054 & & $(0.093)$ & & & 0.9282 & & $(0.207)$ \\
\hline Environment & & & & -0.032 & & $(0.143)$ & & & 0.6491 & & $(0.273)$ \\
\hline Community development & & & & -0.176 & * & $(0.070)$ & & & 0.9010 & & $(0.149)$ \\
\hline Legal advice & & & & -0.037 & & $(0.076)$ & & & 0.9367 & & $(0.160)$ \\
\hline Philanthropic assoc & & & & -0.058 & & $(0.091)$ & & & 0.8643 & & $(0.190)$ \\
\hline International & & & & -0.447 & & $(0.245)$ & & & 0.2881 & & $(0.290)$ \\
\hline Religion & & & & -0.337 & * & $(0.140)$ & & & 0.6935 & & $(0.254)$ \\
\hline Region & & & & Yes & & & & & Yes & & \\
\hline$N$ & 5071 & & & 4582 & & & & & & & \\
\hline$R^{2}$ & 0.308 & & & 0.354 & & & & & & & \\
\hline
\end{tabular}

Notes to table: $* * * \mathrm{p}<0.01 ; * * \mathrm{p}<0.05 ; * \mathrm{p}<0.10$.

For definition of criteria, see section 3.2; Amount requested: the amount of funding the charity asked for in its application. Funding for services/staff/ capital: the main purpose for which funding was sought (see Box, section 3.1). Funding for development; whether the activities are new or additional. Total on table: the total amount of funding requested by the other applications at the same meeting. Quarter: the quarter in which the committee meeting took place; Social services - Religion: main activities of the charity (ICNPO classification). 
Table 4: Non-missing income data, by period before/after committee decision

\begin{tabular}{cccc}
\hline $\begin{array}{c}\text { Periods before/ } \\
\text { after decision }\end{array}$ & $\begin{array}{c}\text { Proportion } \\
\text { nonmissing income } \\
\text { (all applicants) }\end{array}$ & $\begin{array}{c}\text { Proportion } \\
\text { nonmissing income } \\
\text { (successful } \\
\text { applicants) }\end{array}$ & $\begin{array}{c}\text { Proportion } \\
\text { nonmissing income } \\
\text { (unsuccessful } \\
\text { applicants) }\end{array}$ \\
\hline-5 & 0.727 & 0.724 & 0.739 \\
-4 & 0.736 & 0.730 & 0.749 \\
-3 & 0.790 & 0.780 & 0.807 \\
-2 & 0.828 & 0.820 & 0.841 \\
-1 & 0.885 & 0.886 & 0.883 \\
0 & 0.916 & 0.928 & 0.896 \\
1 & 0.905 & 0.926 & 0.873 \\
2 & 0.893 & 0.911 & 0.868 \\
3 & 0.876 & 0.897 & 0.852 \\
4 & 0.847 & 0.863 & 0.823 \\
5 & 0.824 & 0.885 & 0.756 \\
Total & 0.861 & & 0.854 \\
\hline
\end{tabular}




\section{Table 5: Characteristics of successful/ rejected applications}

Full sample $\quad$ Balanced sample $\quad$ Within meeting marginal $\quad$ Across meeting marginal applications applications

\begin{tabular}{|c|c|c|c|c|c|c|c|c|}
\hline & Offered & Rejected & Offered & Rejected & Offered & Rejected & Offered & Rejected \\
\hline Total score $(0-6)$ & 5.01 & $4.25^{*}$ & 5.01 & $4.27 *$ & 4.80 & $4.67 *$ & 4.46 & $5.31 *$ \\
\hline Income $\left(£^{\prime} 000\right)$ & $£ 4,570$ & $£ 3,915$ & $£ 4,667$ & $£ 4,149$ & $£ 3,906$ & $£ 4,590$ & $£ 3,631$ & $£ 4,065$ \\
\hline \multicolumn{9}{|l|}{ Type of charity } \\
\hline Culture & 0.032 & 0.039 & 0.028 & 0.038 & 0.036 & 0.043 & 0.042 & 0.039 \\
\hline Education & 0.047 & 0.054 & 0.045 & 0.057 & 0.046 & 0.054 & 0.062 & 0.042 \\
\hline Health & 0.086 & 0.076 & 0.086 & 0.079 & 0.084 & 0.069 & 0.072 & 0.078 \\
\hline Social services & 0.396 & 0.333 & 0.399 & 0.332 & 0.386 & 0.346 & 0.376 & 0.373 \\
\hline Environment & 0.029 & 0.034 & 0.028 & 0.032 & 0.029 & 0.038 & 0.035 & 0.032 \\
\hline Community development & 0.164 & 0.201 & 0.160 & 0.203 & 0.173 & 0.199 & 0.183 & 0.159 \\
\hline Legal advice & 0.140 & 0.132 & 0.141 & 0.128 & 0.143 & 0.119 & 0.147 & 0.139 \\
\hline Philanthropic intermediaries & 0.072 & 0.078 & 0.077 & 0.079 & 0.072 & 0.081 & 0.099 & 0.071 \\
\hline International & 0.007 & 0.014 & 0.007 & 0.015 & 0.006 & 0.010 & 0.009 & 0.016 \\
\hline Religious & 0.027 & 0.038 & 0.028 & 0.038 & 0.029 & 0.038 & 0.028 & 0.022 \\
\hline Requested amount & $£ 165,871$ & $£ 180,918^{*}$ & $£ 165,261$ & $£ 180,072 *$ & $£ 164,957$ & $£ 183,978 *$ & $£ 165,582$ & $£ 182,617^{*}$ \\
\hline \multicolumn{9}{|l|}{ Nature of funding } \\
\hline Funding for services & 0.806 & 0.788 & 0.803 & 0.777 & 0.812 & 0.801 & 0.783 & 0.815 \\
\hline Funding for staff & 0.097 & 0.112 & 0.096 & $0.115^{*}$ & 0.095 & 0.104 & 0.086 & $0.130 *$ \\
\hline Funding for capital & 0.097 & 0.099 & 0.100 & 0.106 & 0.081 & $0.104 *$ & 0.131 & $0.055^{*}$ \\
\hline \#apps at meeting $(/ 10)$ & 5.86 & 5.86 & 5.92 & 5.90 & 6.34 & 6.36 & 5.99 & $6.97 *$ \\
\hline Total $£$ on the table ( $\left.£^{\prime} m\right)$ & 9.54 & $9.91 *$ & 9.67 & 9.96 & 10.40 & 10.77 & 9.75 & $11.74 *$ \\
\hline Q1 & 0.340 & 0.336 & 0.338 & 0.328 & 0.343 & 0.366 & 0.322 & 0.354 \\
\hline Q2 & 0.118 & $0.171 *$ & 0.123 & $0.177 *$ & 0.121 & $0.182 *$ & 0.092 & $0.214^{*}$ \\
\hline Q3 & 0.299 & 0.312 & 0.293 & 0.310 & 0.297 & 0.303 & 0.318 & 0.262 \\
\hline Q4 & 0.242 & $0.180 *$ & 0.245 & 0.185 & 0.254 & $0.149 *$ & 0.267 & $0.169 *$ \\
\hline $\mathrm{N}$ & 3082 & 1989 & 2670 & 1688 & 1892 & 1241 & 1273 & 308 \\
\hline
\end{tabular}

Notes to table: For definition of criteria, see section 2.2; Income refers to the mean observed income prior to the committee decision; \#apps at meeting refers to the number of applications considered at the same meeting; Total on table refers to the total amount of funding requested by the other applications at the same meeting. Q1 - Q4 refers to the quarter in which the committee meeting took place; Balanced sample refers to applications for which the propensity score is on a common support. Within meeting marginals are applications with a total score between the minimum score of successful applications at the same meeting and the maximum score of the rejected applications at the same meeting; Across meeting marginals are accepted applications that scored below the mean overall score of (all) successful applications and rejected applications that scored above the mean overall score of (all) successful applications.

* indicates that the difference across the successful/ unsuccessful applications is significant at the $5 \%$ level 
Table 6: Fixed effects regression results - the average effect of getting a grant

\begin{tabular}{|c|c|c|c|c|c|c|}
\hline & ALL & $\begin{array}{c}\text { Micro } \\
<£ 10 \mathrm{k}\end{array}$ & $\begin{array}{c}\text { Small } \\
£ 10 \mathrm{k}-£ 100 \mathrm{k}\end{array}$ & $\begin{array}{c}\text { Medium } \\
£ 100 \mathrm{k}-£ 1 \mathrm{~m}\end{array}$ & $\begin{array}{c}\text { Large } \\
£ 1 \mathrm{~m}-£ 5 \mathrm{~m}\end{array}$ & $\begin{array}{l}\text { Major } \\
£ 5 \mathrm{~m}+\end{array}$ \\
\hline \multicolumn{7}{|c|}{ a. All applications: Dependent variable $=$ log total income } \\
\hline Treatment $\left(\gamma_{1}\right)$ & $\begin{array}{c}0.212^{* * *} \\
(0.014)\end{array}$ & $\begin{array}{c}0.579 * * \\
(0.239)\end{array}$ & $\begin{array}{c}0.350 * * * \\
(0.036)\end{array}$ & $\begin{array}{c}0.175^{* * *} \\
(0.016)\end{array}$ & $\begin{array}{c}0.053 * * \\
(0.023)\end{array}$ & $\begin{array}{l}-0.038^{*} \\
(0.020)\end{array}$ \\
\hline $\mathrm{N}$ & 24,204 & 608 & 5,753 & 12,653 & 2,882 & 2,308 \\
\hline \multicolumn{7}{|c|}{ b. All applications: Dependent variable $=$ log total expenditure } \\
\hline Treatment $\left(\gamma_{1}\right)$ & $\begin{array}{c}0.181^{* * * *} \\
(0.014) \\
24,207\end{array}$ & $\begin{array}{c}0.246 \\
(0.261) \\
607\end{array}$ & $\begin{array}{c}0.278 * * * \\
(0.036) \\
5,754\end{array}$ & $\begin{array}{c}0.161 * * * \\
(0.015) \\
12,656\end{array}$ & $\begin{array}{c}0.039 \\
(0.022) \\
2,882\end{array}$ & $\begin{array}{c}-0.037^{*} \\
(0.020) \\
2.308\end{array}$ \\
\hline \multicolumn{7}{|c|}{ c. Balanced sample: Dependent variable = log total income } \\
\hline Treatment $\left(\gamma_{1}\right)$ & $\begin{array}{c}0.208 * * * \\
(0.014) \\
23,295 \\
\end{array}$ & $\begin{array}{c}0.566^{* *} \\
(0.242) \\
594 \\
\end{array}$ & $\begin{array}{c}0.345^{* * *} \\
(0.037) \\
5,503 \\
\end{array}$ & $\begin{array}{c}0.173 * * * \\
(0.016) \\
12,113\end{array}$ & $\begin{array}{c}0.057 * * * \\
(0.022) \\
2,802\end{array}$ & $\begin{array}{c}-0.036^{*} \\
(0.020) \\
2,283\end{array}$ \\
\hline \multicolumn{7}{|c|}{ d. Within meeting marginals: Dependent variable = log total income } \\
\hline Treatment $\left(\gamma_{1}\right)$ & $\begin{array}{c}0.214 * * * \\
(0.018) \\
14,931\end{array}$ & $\begin{array}{c}-0.491 \\
(0.382) \\
338\end{array}$ & $\begin{array}{c}0.367 * * * \\
(0.049) \\
3,521\end{array}$ & $\begin{array}{c}0.155^{* * *} \\
(0.020) \\
7,878\end{array}$ & $\begin{array}{c}0.081^{* *} \\
(0.028) \\
1,762\end{array}$ & $\begin{array}{c}-0.053^{*} \\
(0.027) \\
1,432\end{array}$ \\
\hline \multicolumn{7}{|c|}{ e. Across meeting marginals: Dependent variable $=$ log total income } \\
\hline Treatment $\left(\gamma_{1}\right)$ & $\begin{array}{c}0.203 * * * \\
(0.034) \\
7,427\end{array}$ & $\begin{array}{c}0.103 \\
(1.031) \\
240\end{array}$ & $\begin{array}{c}0.372 * * * \\
(0.089) \\
1,851\end{array}$ & $\begin{array}{c}0.093 * * \\
(0.040) \\
3,899\end{array}$ & $\begin{array}{c}0.043 \\
(0.048) \\
827\end{array}$ & $\begin{array}{c}0.015 \\
(0.042) \\
610\end{array}$ \\
\hline $\begin{array}{l}\text { Notes to table: A } \\
\text { to applications fo } \\
\text { with a total score } \\
\text { score of the rejec } \\
\text { scored below the } \\
\text { mean }\end{array}$ & $\begin{array}{l}\text { ressions in } \\
\text { ich the pro } \\
\text { veen the } m\end{array}$ & year dun & $\begin{array}{l}\text { s. } * * * p<0.0 \\
\text { a common su } \\
\text { ccessful appli } \\
\text { g; Across me } \\
\text { ful applicatio }\end{array}$ & $\begin{array}{l}* * \mathrm{p}<0.05 ; * \\
\text { rt. Within me } \\
\text { ions at the san } \\
\text { ag marginals }\end{array}$ & $\begin{array}{l}0.10 \text {; Balar } \\
\text { marginals } \\
\text { eeting and } \\
\text { cepted app } \\
\text { ations that }\end{array}$ & $\begin{array}{l}\text { mple refer } \\
\text { olications } \\
\text { ximum } \\
\text { ns that } \\
\text { above the }\end{array}$ \\
\hline
\end{tabular}


Table 7: Fixed effects regression results - the total effect per pound of grant money

\begin{tabular}{|c|c|c|c|c|c|}
\hline & $\begin{array}{l}\text { Micro } \\
<£ 10 \mathrm{k} \\
\end{array}$ & $\begin{array}{l}\text { Small } \\
£ 10 \mathrm{k}-£ 100 \mathrm{k}\end{array}$ & $\begin{array}{l}\text { Medium } \\
£ 100 \mathrm{k}-£ 1 \mathrm{~m}\end{array}$ & $\begin{array}{l}\text { Large } \\
£ 1 \mathrm{~m}-£ 5 \mathrm{~m} \\
\end{array}$ & $\begin{array}{l}\text { Major } \\
£ 5 \mathrm{~m}+ \\
\end{array}$ \\
\hline \multicolumn{6}{|c|}{ a. All applicants } \\
\hline Post $x £$ Amount $\left(\gamma_{2}\right)$ & $\begin{array}{l}0.283^{* * *} \\
(0.059)\end{array}$ & $\begin{array}{l}0.233 * * * \\
(0.018)\end{array}$ & $\begin{array}{l}0.227 * * * \\
(0.035)\end{array}$ & $\begin{array}{l}-0.307 \\
(0.629)\end{array}$ & $\begin{array}{l}-2.178 \\
(4.206)\end{array}$ \\
\hline $\begin{array}{l}\mathrm{p} \text {-value }\left(\gamma_{2}=1\right) \\
\mathrm{N}\end{array}$ & $\begin{array}{l}{[0.000]} \\
282\end{array}$ & $\begin{array}{l}{[0.000]} \\
3049\end{array}$ & $\begin{array}{l}{[0.000]} \\
6809\end{array}$ & $\begin{array}{l}{[0.038]} \\
1548\end{array}$ & $\begin{array}{l}{[0.450]} \\
1233\end{array}$ \\
\hline \multicolumn{6}{|c|}{ Up to and including Year 1} \\
\hline Post $x £$ Amount $\left(\gamma_{2}\right)$ & $\begin{array}{l}1.045^{* * *} \\
(0.293)\end{array}$ & $\begin{array}{l}0.571 * * * \\
(0.042)\end{array}$ & $\begin{array}{l}0.562 * * * \\
(0.067)\end{array}$ & $\begin{array}{l}0.473 \\
(0.930)\end{array}$ & $\begin{array}{l}-6.553 \\
(7.520)\end{array}$ \\
\hline $\begin{array}{l}\mathrm{p} \text {-value }\left(\gamma_{2}=1\right) \\
\mathrm{N}\end{array}$ & $\begin{array}{l}{[0.877]} \\
388\end{array}$ & $\begin{array}{l}{[0.000]} \\
4036\end{array}$ & $\begin{array}{l}{[0.000]} \\
9016\end{array}$ & $\begin{array}{l}{[0.571]} \\
2056\end{array}$ & $\begin{array}{l}{[0.315]} \\
1644\end{array}$ \\
\hline \multicolumn{6}{|c|}{ Up to and including Year 2} \\
\hline Post $\mathrm{x} £$ Amount $\left(\gamma_{2}\right)$ & $\begin{array}{l}1.101 * * \\
(0.497)\end{array}$ & $\begin{array}{l}0.866 * * * \\
(0.065)\end{array}$ & $\begin{array}{l}0.897 * * * \\
(0.098)\end{array}$ & $\begin{array}{l}0.777 \\
(1.257)\end{array}$ & $\begin{array}{l}-14.66 \\
(11.43)\end{array}$ \\
\hline $\begin{array}{l}\mathrm{p} \text {-value }\left(\gamma_{2}=1\right) \\
\mathrm{N}\end{array}$ & $\begin{array}{l}{[0.839]} \\
485\end{array}$ & $\begin{array}{l}{[0.041]} \\
4879 \\
\end{array}$ & $\begin{array}{l}{[0.294]} \\
10854 \\
\end{array}$ & $\begin{array}{l}{[0.858]} \\
2470\end{array}$ & $\begin{array}{l}{[0.171]} \\
1973\end{array}$ \\
\hline \multicolumn{6}{|c|}{ Up to and including Year 3} \\
\hline Post $\mathrm{x} £$ Amount $\left(\gamma_{2}\right)$ & $\begin{array}{l}1.196^{*} \\
(0.622)\end{array}$ & $\begin{array}{l}1.037 * * * \\
(0.087)\end{array}$ & $\begin{array}{l}1.126^{* * *} \\
(0.139)\end{array}$ & $\begin{array}{l}1.867 \\
(1.590)\end{array}$ & $\begin{array}{l}-22.09 \\
(15.99)\end{array}$ \\
\hline p-value $\left(\gamma_{2}=1\right)$ & {$[0.753]$} & {$[0.673]$} & {$[0.364]$} & {$[0.586]$} & [0.149] \\
\hline $\mathrm{N}$ & 558 & 5420 & 12036 & 2735 & 2182 \\
\hline \multicolumn{6}{|c|}{ Up to and including Year 4} \\
\hline Post $\mathrm{x} £$ Amount $\left(\gamma_{2}\right)$ & $\begin{array}{l}1.332^{*} \\
(0.740)\end{array}$ & $\begin{array}{l}1.239 * * * \\
(0.109)\end{array}$ & $\begin{array}{l}1.472 * * * \\
(0.177)\end{array}$ & $\begin{array}{l}2.947 \\
(1.963)\end{array}$ & $\begin{array}{l}-29.75 \\
(20.18)\end{array}$ \\
\hline p-value $\left(\gamma_{2}=1\right)$ & {$[0.654]$} & {$[0.028]$} & {$[0.008]$} & {$[0.322]$} & [0.128] \\
\hline $\mathrm{N}$ & & 5690 & 12577 & 2856 & 2290 \\
\hline \multicolumn{6}{|c|}{ b. Balanced sample: Up to and including Year 4} \\
\hline Post $\mathrm{x} £$ Amount $\left(\gamma_{2}\right)$ & $\begin{array}{l}1.337^{*} \\
(0.748)\end{array}$ & $\begin{array}{l}1.255^{* * *} \\
(0.113)\end{array}$ & $\begin{array}{l}1.481 * * * \\
(0.181)\end{array}$ & $\begin{array}{l}2.645 \\
(1.993)\end{array}$ & $\begin{array}{l}-29.313 \\
(20.275)\end{array}$ \\
\hline p-value $\left(\gamma_{2}=1\right)$ & {$[0.653]$} & {$[0.024]$} & {$[0.008]$} & {$[0.410]$} & {$[0.135]$} \\
\hline $\mathrm{N}$ & & & 12040 & 2776 & 2265 \\
\hline \multicolumn{6}{|c|}{ c. Within meeting marginals: Up to and including Year 4} \\
\hline Post $\mathrm{x} £$ Amount $\left(\gamma_{2}\right)$ & $\begin{array}{l}1.918^{*} \\
(0.999)\end{array}$ & $\begin{array}{l}1.209 * * * \\
(0.143)\end{array}$ & $\begin{array}{l}0.913 * * * \\
(0.222)\end{array}$ & $\begin{array}{l}4.039 * * \\
(1.629)\end{array}$ & $\begin{array}{l}-95.802 * * * \\
(24.28)\end{array}$ \\
\hline p-value $\left(\gamma_{2}=1\right)$ & [0.359] & {$[0.145]$} & {$[0.697]$} & {$[0.062]$} & {$[0.000]$} \\
\hline $\mathrm{N}$ & 331 & 3496 & 7854 & 1746 & 1424 \\
\hline \multicolumn{6}{|c|}{ d. Across meeting marginals: Up to and including Year 4} \\
\hline Post $\mathrm{x} £$ Amount $\left(\gamma_{2}\right)$ & $\begin{array}{l}2.809 * * \\
(1.338)\end{array}$ & $\begin{array}{l}1.239 * * * \\
(0.187)\end{array}$ & $\begin{array}{l}1.161 * * * \\
(0.305)\end{array}$ & $\begin{array}{l}6.005^{* *} \\
(2.478)\end{array}$ & $\begin{array}{l}-38.119 \\
(41.252)\end{array}$ \\
\hline p-value $\left(\gamma_{2}=1\right)$ & {$[0.178]$} & {$[0.201]$} & {$[0.597]$} & {$[0.044]$} & [0.343] \\
\hline $\mathrm{N}$ & 234 & 1833 & 3878 & 820 & 608 \\
\hline
\end{tabular}


Table 8: Heterogeneous effects - the total effect per pound of grant money

\section{Medium charities \\ Dependent variable $=$ Income $(£)$}

\begin{tabular}{lcc}
\hline & Up to and including Year 2 & Up to and including Year 4 \\
\hline a. By grant type & $1.297^{* * *}$ & $2.231^{* * *}$ \\
Treatment & $(0.077)$ & $(0.200)$ \\
& -0.107 & -0.650 \\
Treatment_staff & $(0.447)$ & $(0.793)$ \\
& $-1.111^{* * *}$ & $-2.031^{* * *}$ \\
Treatment_capital & $(0.445)$ & $(0.789)$ \\
& 11551 & 13575 \\
$\mathrm{~N}$ & & \\
b. By cause & $1.021^{* * *}$ & $1.840^{* * *}$ \\
Treatment & $(0.184)$ & $(0.326)$ \\
& 1.010 & 1.208 \\
Treatment_culture & $(0.692)$ & $(1.229)$ \\
& $-0.886^{*}$ & -0.640 \\
Treatment_education & $(0.505)$ & $(0.890)$ \\
& $0.918^{* *}$ & 0.999 \\
Treatment_health & $(0.397)$ & $(0.700)$ \\
& $1.634^{* * *}$ & $2.334^{* *}$ \\
Treatment_environment & $(0.577)$ & $(1.049)$ \\
& -0.101 & 0.035 \\
Treatment_community & $(0.338)$ & $(0.598)$ \\
Treatment_legal advice & 0.367 & 0.153 \\
& $(0.311)$ & $(0.551)$ \\
Treatment_philanthropy & -0.412 & -0.821 \\
Treatment_international & $(0.363)$ & $(0.644)$ \\
& $1.938^{*}$ & 3.185 \\
Treatment_religion & $(1.165)$ & $(2.081)$ \\
& $2.548^{* * *}$ & $4.244^{* * *}$ \\
$\mathrm{~N}$ & $(0.681)$ & $(1.204)$ \\
\hline & 11551 & 13575 \\
\hline
\end{tabular}


Figure 1: Proportion of successful applications, by score

\section{a. Individual scores}
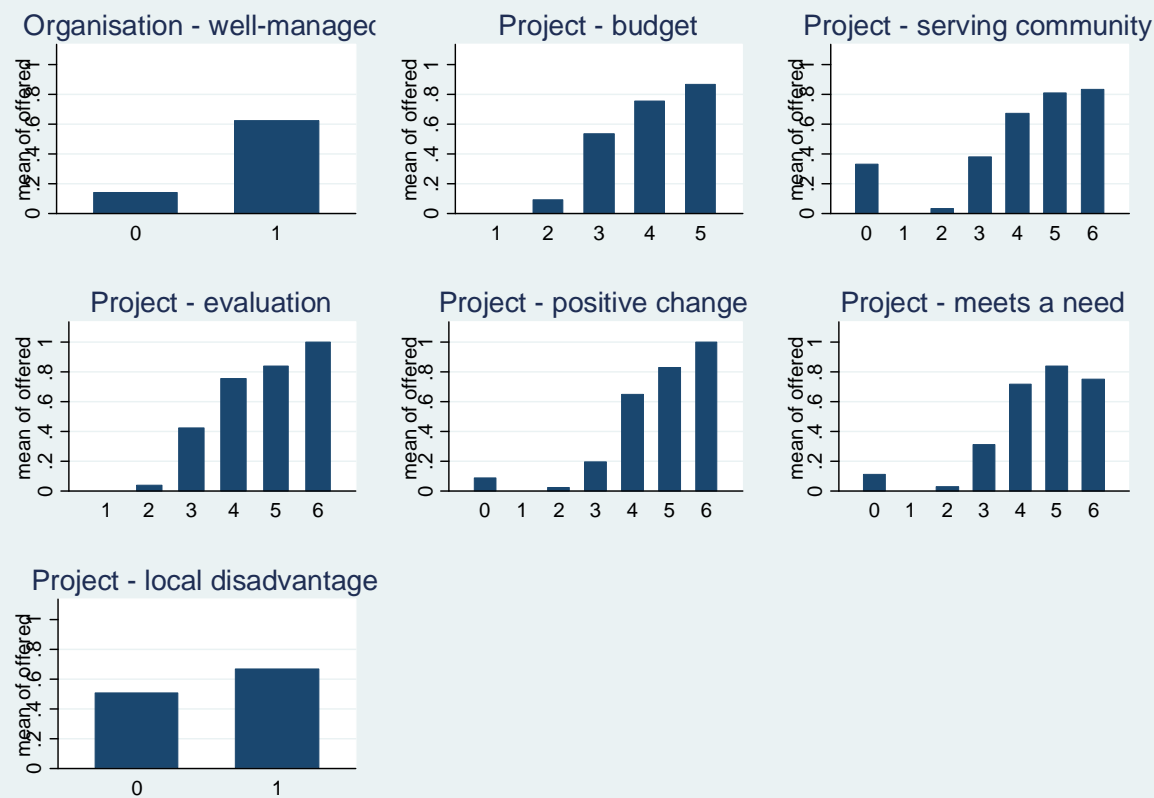

\section{b. Total score}

Total project score

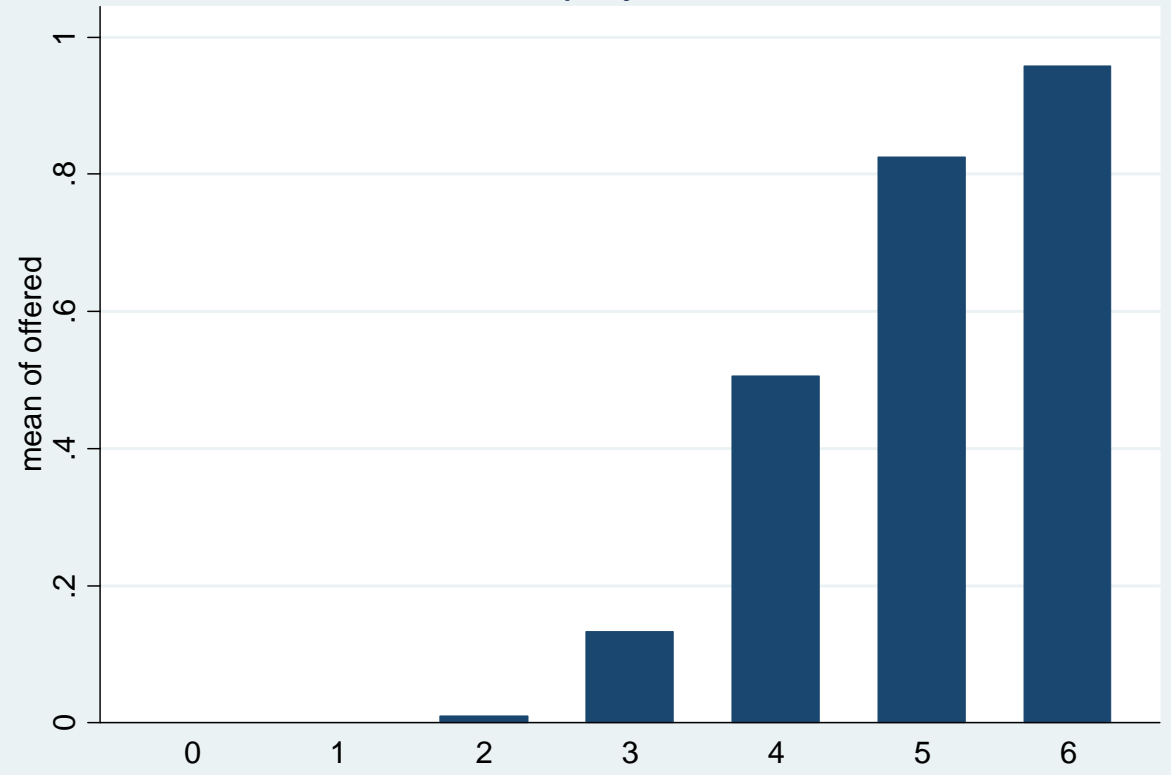


Figure 2: Scores, by committee meeting

a. Minimum score, successful applications and max score, rejected applications

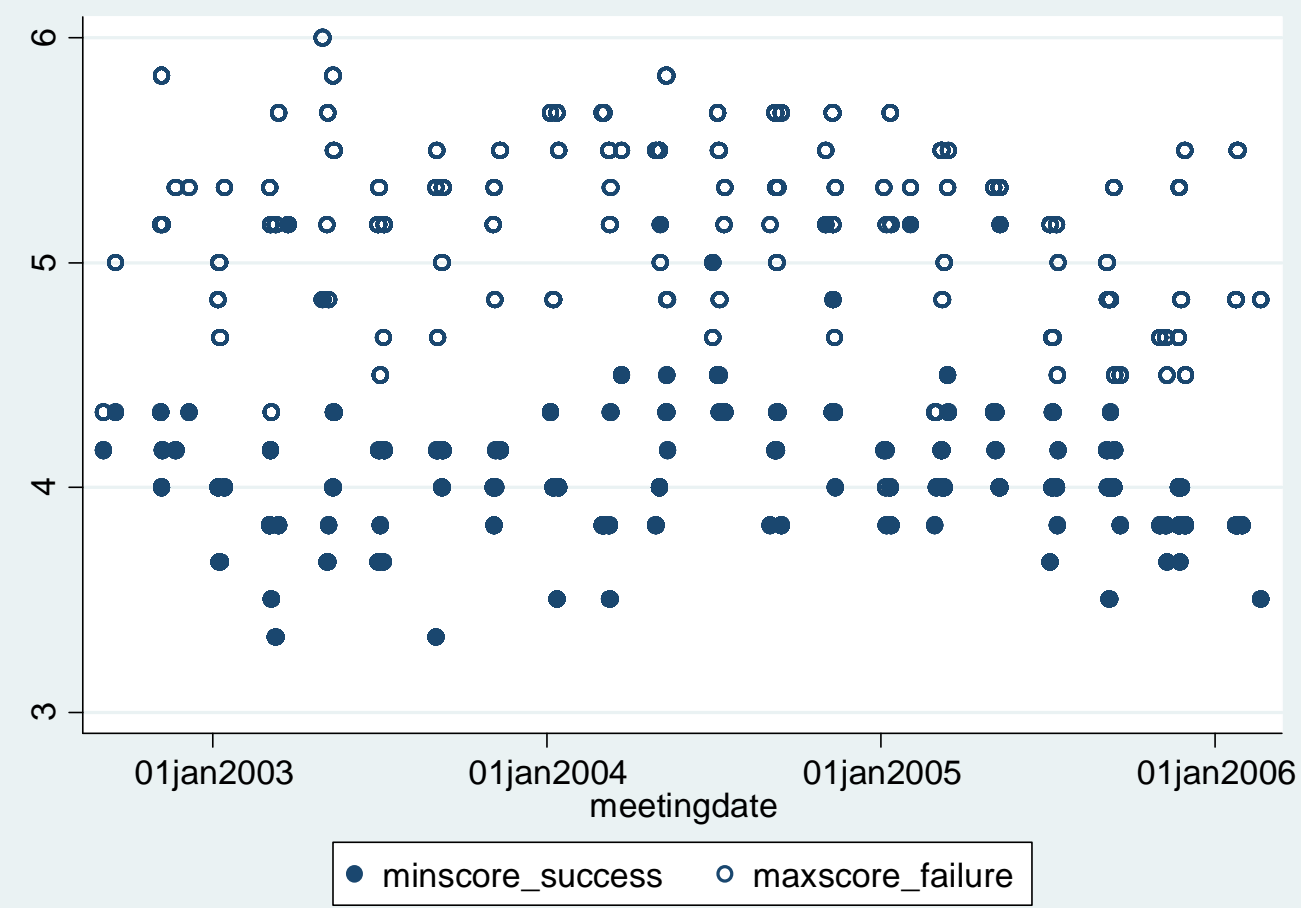

b. Mean score, successful applications

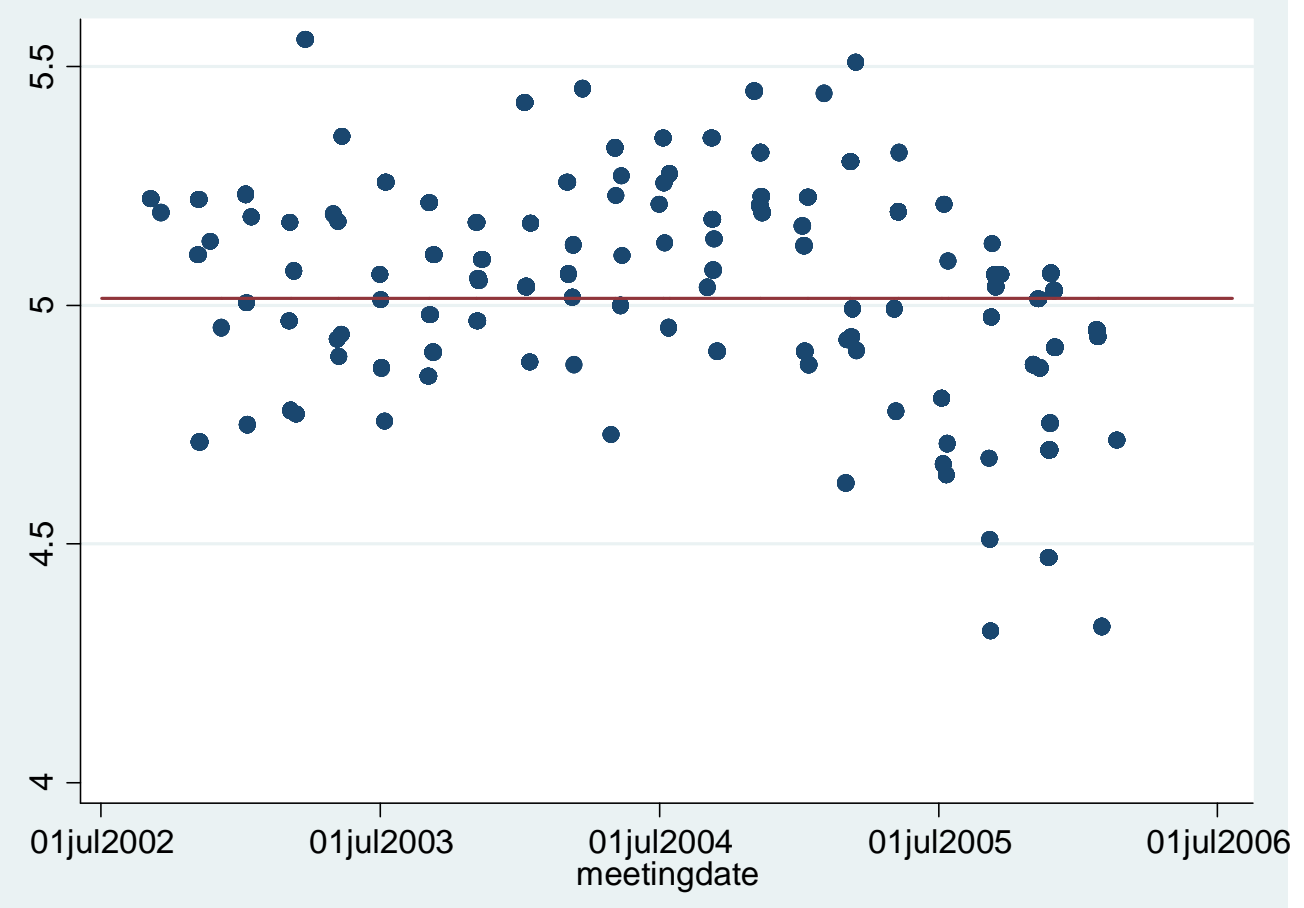




\section{Figure 3: Dynamic effects of being awarded a grant}
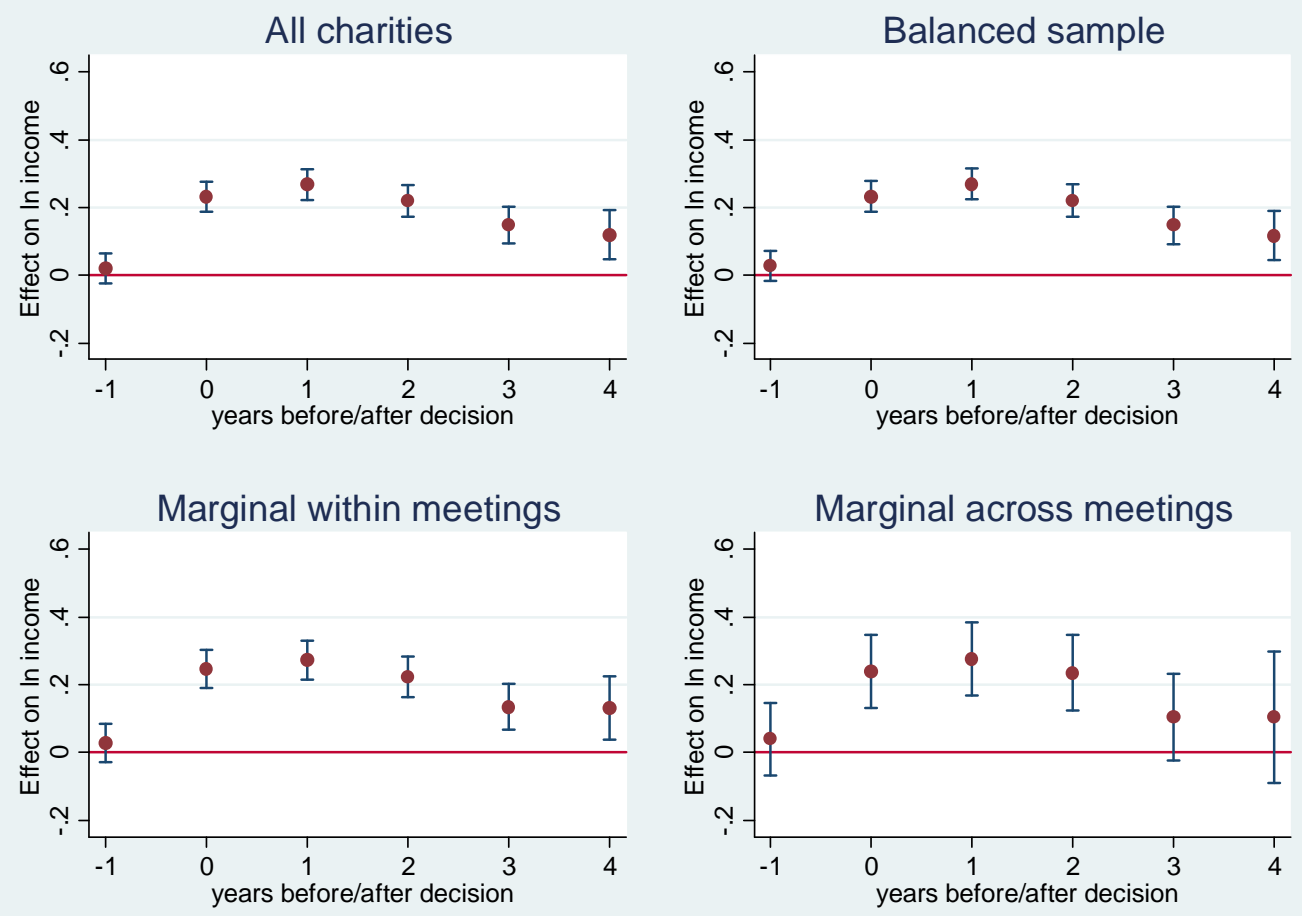


\section{Appendix A1: Scoring for criterion 1}

\section{Criterion 1}

The organisation is well-managed and financially sound.

You may find the following checklists helpful when you consider the application under this criterion. Further information is available in the reference manual, where "Financial guidelines" will help you to interpret the annual report, the accounts, and any auditors' reports, as well as discussing notes and fraud indicators. "Personnel and management guidelines" contain further background about committee and management responsibilities.

\section{Management:}

\begin{tabular}{|c|c|}
\hline $\begin{array}{l}\text { Management } \\
\text { committee }\end{array}$ & $\begin{array}{l}\square \text { Review the composition of the management committee. } \\
\text { - How many trustees/directors are there? } \\
\text { - How are they appointed? } \\
\text { - Is there a rapid turnover or does it rarely change? } \\
\text { - What backgrounds, skills and experience do they have? } \\
\square \text { What expertise do the key personnel have (include the } \\
\text { chairman, treasurer, chief executive, accountant, secretary to } \\
\text { the management committee)? } \\
\square \text { What are the terms of reference for the management } \\
\text { committee? } \\
\square \text { Does the organisation distinguish effectively between } \\
\text { management and govemance? } \\
\square \text { Do committee members attend meetings regularly? } \\
\square \text { What is the quality of information given to committee members } \\
\text { and how often is this information distributed? }\end{array}$ \\
\hline $\begin{array}{l}\text { Staff and } \\
\text { structure }\end{array}$ & $\begin{array}{l}\square \text { If staff are employed, what is the length of service of the } \\
\text { Director and/or senior staff? } \\
\square \text { Is the structure of the organisation fit for the purpose set out in } \\
\text { the constitution? } \\
\square \text { Does the formal structure of the organisation allow management } \\
\text { accountability and control? }\end{array}$ \\
\hline $\begin{array}{l}\text { Management } \\
\text { capacity }\end{array}$ & $\begin{array}{l}\text { Are staff and volunteers adequately supervised and managed? } \\
\text { If in doubt ask about staff and volunteer turnover, as well as } \\
\text { staff sickness levels and seek explanations. } \\
\text { If turnover on management committee is more than } 25 \% \text { in last } \\
\text { year, ask for reasons. }\end{array}$ \\
\hline
\end{tabular}


Financial health:

\begin{tabular}{|c|c|}
\hline Accounts & $\begin{array}{l}\square \text { Is there a large measure of dependency on one particular } \\
\text { source of income? How secure is it in the future? } \\
\square \text { Are there any unusual items such as a surplus or deficit on a } \\
\text { sale of assets, commencement or cessation of a project? } \\
\square \text { What is the ratio of administration costs to total costs? (up to } \\
10 \% \text { is acceptable) } \\
\square \text { What is the ratio of fund-raising costs to fund-raising income (up } \\
\text { to } 15 \% \text { acceptable)? } \\
\square \text { What proportion of income is spent on charitable activities? (at } \\
\text { least } 75 \% \text { should be expected) } \\
\square \text { What trends year on year are evident in costs and revenue? Are } \\
\text { these favourable or unfavourable? } \\
\square \text { Does the organisation have an operating deficit? If so, is it } \\
\text { being tackled, can the applicant explain it, or is it running out of } \\
\text { control? } \\
\square \text { Are the projections achievable for a new organisation? } \\
\square \text { Are administration costs reasonable? } \\
\square \text { Compare the accounts to the previous year. Are there any } \\
\text { significant changes? Why? } \\
\square \text { What are the main changes in income? } \\
\square \text { Are these trends continuing in the current year? } \\
\square \text { Are the major grants secure for the immediate future? } \\
\square \text { What sources of income will be terminated? } \\
\square \text { Have any items of expenditure increased sharply over the } \\
\text { period? } \\
\square \text { Are there any foreseeable increases in expenditure in current or } \\
\text { future years? } \\
\square \text { Is there any additional information in the notes to the accounts } \\
\text { such as further detail on fixed assets, further details of funds, or } \\
\text { notes on capital commitments and contingent liabilities? }\end{array}$ \\
\hline Balance sheet & $\begin{array}{l}\text { Was the organisation solvent on the date of the balance sheet? } \\
\text { You may want to compare figures with previous year or the } \\
\text { management accounts balance sheet. Check: } \\
\text { - net current assets } \\
\text { - net assets } \\
\text { - } \text { other bank balances/overdraft } \\
\text { - future comming } \\
\text { - contingent liabilities. } \\
\text { A ratio of current assets to current liabilities of 2:1 is ideal. } \\
\text { Rev funds: } \\
\text { - other restricted funds (use specified by donor) } \\
\text { - designated unrestricted funds } \\
\text { - general unrestricted funds. } \\
\text { running costs. } \\
\text { - If fixed assets (buildings) appear, check the provision for } \\
\text { maintenance. } \\
\text { If fixed assets (equipment) appear, check the provision for } \\
\text { depreciation. }\end{array}$ \\
\hline
\end{tabular}




\begin{tabular}{|c|c|}
\hline $\begin{array}{l}\text { Current financial } \\
\text { information }\end{array}$ & $\begin{array}{l}\square \text { Review the current year's budget. Review the management } \\
\text { accounts and cash flow statements since the beginning of the } \\
\text { current financial year. Are these up to date? } \\
\square \text { Ensure that financial information is used by management and } \\
\text { that appropriate action is taken as a result of this information. } \\
\text { Any substantial surplus/deficit arising should be investigated. } \\
\square \text { Note any changes in operations such as: } \\
\text { - commencement or cessation of projects } \\
\text { - changes in streams of income (increase/decrease in grants, } \\
\text { donations etc.) } \\
\text { - different pattern of costs and unusual items } \\
\square \text { Review solvency and especially bank balances/overdraft . }\end{array}$ \\
\hline $\begin{array}{l}\text { New } \\
\text { organisations }\end{array}$ & $\begin{array}{l}\square \text { Organisations yet to start operations should produce income } \\
\text { and expenditure projections for the whole organisation for the } \\
\text { period of the grant. } \\
\square \text { Organisations which have commenced operations but are not } \\
\text { yet due to prepare an annual report and financial statements } \\
\text { should produce: } \\
\text { - budgets } \\
\text { - management accounts showing actual income/expenditure } \\
\text { compared with budgets } \\
\text { - where budget and management are not available, ask for } \\
\text { copies of cash book and bank statements. }\end{array}$ \\
\hline Bank account & $\begin{array}{l}\square \text { Does the organisation have a bank account which requires at } \\
\text { least two signatories on each cheque? } \\
\square \text { If a new organisation, when was the account opened? If no } \\
\text { transactions have taken place, are there valid reasons (e.g. new } \\
\text { organisations may have opened their first account simply to } \\
\text { meet Community Fund requirements)? } \\
\square \text { Is there a cheque requisition system? } \\
\square \text { How often is a bank reconciliation carried out? }\end{array}$ \\
\hline $\begin{array}{l}\text { Management of } \\
\text { finances }\end{array}$ & $\begin{array}{l}\square \text { Is there a separate finance committee or is finance an important } \\
\text { part of the agenda for trustees, directors, or management } \\
\text { committee meetings? } \\
\square \text { If short term projected income is less than expenditure, what are } \\
\text { they doing about it? } \\
\square \text { Are the skills and experience of the treasurer and/ or financial } \\
\text { manager suitable for this type and size of organisation? } \\
\square \text { Who is responsible for the budget of the overall organisation? } \\
\square \text { How is spending controlled? } \\
\text { - Who orders goods and services? } \\
\text { Who authorises expenditure? } \\
\square \text { Who has control over donations received and spent? } \\
\square \text { Are internal financial policies and controls understood and acted } \\
\text { upon? } \\
\square \text { Are budgets set and management accounts reviewed regularly? } \\
\square \text { Are the trustees, director, management committee members, } \\
\text { staff experienced in handling substantial sums of money? } \\
\square \text { What does the history of the organisation say about its likely } \\
\text { future? }\end{array}$ \\
\hline
\end{tabular}




\begin{tabular}{|c|c|}
\hline & $\begin{array}{l}\square \text { Check for obvious signs of relationships on the management } \\
\text { body (such as same name, same address). If any such } \\
\text { relationships exist, can related people be both signatories on a } \\
\text { cheque? } \\
\square \text { What procedures or policies does the organisation have to } \\
\text { ensure that there are no conflicts of interest when decisions } \\
\text { need to be made? } \\
\text { NOTE: If you are aware that there are relationships, and are } \\
\text { confident that there are appropriate controls are in place, } \\
\text { you should make reference to this within your assessment } \\
\text { report. }\end{array}$ \\
\hline $\begin{array}{l}\text { Legal and } \\
\text { statutory } \\
\text { requirements }\end{array}$ & $\begin{array}{l}\text { Is the organisation aware of and following any legal } \\
\text { requirements imposed by its structure and constitution (such } \\
\text { as reporting accounts or charitable registration? If the } \\
\text { governing document refers to the Charity Commission, is it a } \\
\text { registered charity? If not, why do they make such } \\
\text { references? } \\
\square \text { Is the applicant aware of and following all legal requirements } \\
\text { relating to managing the project and staff (such as equal } \\
\text { opportunities legislation, health and safety and employment } \\
\text { law)? } \\
\square \text { What will they do to ensure that they keep up to date with } \\
\text { these throughout the life of the project? }\end{array}$ \\
\hline $\begin{array}{l}\text { Constitutional } \\
\text { arrangements }\end{array}$ & $\begin{array}{l}\square \text { Have you checked whether the organisation is planning any } \\
\text { constitutional changes, including merger or incorporation? } \\
\square \text { If so, will this happen before or after any award would be } \\
\text { made? } \\
\square \text { If before, will this affect the organisation's legal identity? If it } \\
\text { does, you should not recommend funding the application (as } \\
\text { described in "Changes in legal identity" in the reference } \\
\text { manual). } \\
\square \text { If after, does this lead to any concerns about the future } \\
\text { management of the project? }\end{array}$ \\
\hline
\end{tabular}

